\title{
A SIMULATION-BASED EVALUATION FOR A STRATEGIC RESIDENTIAL WASTEWATER NETWORK MASTER PLAN
}

\author{
Esra Aleisa \\ Osama Alkassar \\ Abrar Al-Jadi \\ Sarah Al-Sabah \\ Rana Mahmoud Hishmi \\ Industrial and Management Systems Engineering Department \\ Kuwait University \\ Khaldia Bldg. \# 8KH \\ Kuwait, Safat 13060, KUWIAT
}

\begin{abstract}
This paper provides a study for the current and prospective strategic wastewater infrastructure in an entire country. The new master plan will be implemented no later than the year 2045, including building new treatment plans and installing new pumping stations into the wastewater network. Because this project is of major investment, simulation modeling is necessary to predict the performance of the wastewater network included in the sewage master plan. The study covers forecasted demand, seasonality fluctuations, and rainfall effect and fits them to theoretical distributions. The model was statistically validated. The simulations revealed how the wastewater treatment plants (WWTP) and pumping stations will perform with respect to their capacities. The study aims to reduce wastewater dumping and achieve full utilization of treated effluent.
\end{abstract}

\section{INTRODUCTION}

Due to the rapid growth in population, rapid increase in urban development and life style, the state of Kuwait is facing a challenge in meeting the demand for the ever increasing water consumption and treatment. Authorities aimed to treat and reuse domestic wastewaters to: elevate the strain on depleting scarce ground water wells, provide a cheaper alternative than desalinated water, reduce the environmental adverse impact of desalination plants, and eliminate the dumping of wastewaters to coastal areas or terrestrial landfills. This paper provides a simulation study of the entire current wastewater network in the Middle Eastern country, Kuwait. It also includes assessing the master plan suggested by the Minstery of Public Works (MPW). The new master plan will be take place no later than the year 2045, including building new treatment plans and installing new pumping stations into the wastewater network. Simulation software was used to model both the current and the planned future wastewater network. The results are used to assess the new wastewater with respect to demand of forecasted population and urban activity. The study starts with a field data collection of monthly inflows and treated effluent quantities, measuring seasonality and marking GPS location to assist in pipeline measurements. Detailed flowcharts were created to understand the infrastructure connections. The simulation for both the current and prospective country strategic plan were constructed and statistically validated. The capacities for the future plans were then investigated using the built simulation model. 


\section{SIMULATION AND WASTEWATER TREAMENT}

In the area of wastewater treatment, discrete-event simulation has been applied repeatedly to estimate capacities, analyze and balance effluent water flows and improve overall performance measures (Andreottola et al. 1997; Batstone et al. 1997; Filali-Meknassi et al. 2005; Langergraber 2007; Muschalla et al. 2008; Samuelsson et al. 2001). Ceric (1993) have used discrete-event simulation to model a solidwaste processing system which is to be installed in Zagreb, Croatia. Printemps et al. (2004) have utilized simulation to develop simplified mathematical tool able to reproduce and anticipate the behavior of certain Wastewater Treatment Plant (WWTP) discussed in their study. In Glen et al. (1990) a discrete-event simulation model was created using General-Purpose Simulation System (GPSS) to investigation of the batch operation of a poultry processing WWTP. Huang et al. (2007) have applied simulation on higher level to assess potential dynamic evolution of environmental systems caused by various strategies. In addition, Ferrer et al. (2008) presents a software tool to design, simulate and optimize WWTPs. The program is called DESASS (DEsign and Simulation of Activated Sludge Systems)

\section{CURRENT WASTEWATER PLANTS}

In response to the severe environmental influence of dumping wastewaters into landfills or into the sea, and due to scarcity of water in the Kuwait region, the sanitary sector at the Ministry of Public Works (MPW) in Kuwait, established WWTPs around the country in late 1950's. This made Kuwait one of the first Arabian Gulf states to build a wastewater network (Lidstone 2009). By 1984, all secondary treatment wastewater plants were upgraded to tertiary effluent quality when working on capacity (Al Khizzy 2009). Originally, there were three WWTPs in Kuwait Ardiya, Riqqa and Al Jahra. Together receiving a total of $200,000 \mathrm{~m}^{3} / \mathrm{d}$. The main source of wastewater arriving at the plants is municipal wastewater, which is a combination of the water and carried wastes removed from residential, institutional, and commercial establishments together with infiltration water, surface water, and storm water (Enezi, Hamoda, and Fawzi 2004). At the Ardiya station, the Carbon Oxygen Demand (COD) removal efficiency was $78 \%$ which was considered unacceptable. This might have been attributed to the technology used or due to overloading the system (Ghobrial 1993). As a result, Al-Ardiya WWTP was transformed to a pumping station and a pre-treatment to remove coarse particles and degreasing. Al Ardiya plant also contained two circular buffer tanks to balance effluent variation to regulate the outflow. The station is also equipped with a scrubber system to treat air extracted and reduce emitted odors (Anonymous 2009). Also, although overloading Al-Jahra WWTP did in fact affect the tertiary treated effluent at some point in time, where the effluent didn't meet the MPW water quality criteria (Ghobrial 1993). The Biological treatment and technology was upgraded later on to meet the national standards by both the Ministry of Public Works and the Ministry of Health (Karam 2010). Currently, Kuwait has four WWTPs in operation; these are listed in Table 1. Commenced in 2005, Al-Sulaibiya wastewater treatment and reclamation plant is the largest facility that uses Reverse Osmosis (RO) and Ultra Filtration (UF) membrane water purification facility. The facility was constructed with an initial capacity of $425,000 \mathrm{~m}^{3} / \mathrm{d}$ to treat domestic wastewaters to potable quality for non-potable use. Just after few years in operation, the facility became capable of accepting around $500,000 \mathrm{~m}^{3} / \mathrm{d}$, which corresponds to recycling around $64 \%$ of the entire sewage water of the country. Future plans are directed towards expanding the capacity to $600,000 \mathrm{~m}^{3} /$ day. Al-Sulaibiya WWTP receives wastewaters through a $25 \mathrm{~km}$-long main feeder pipeline that conveys a pre-treated flow from the Ardiya pumping station. As discussed earlier, the Ardiya station does receiving, initial screening, degreasing, odor removal and flow regulation. 
Table 1: Current WWTPs in Kuwait

\begin{tabular}{|l|l|l|l|l|}
\hline Plant & Al Riqqa & Al Jahra & Um Al-Hayman & Sulaibiya \\
\hline Constructed & 1982 & 1982 & 2001 & 2002 \\
\hline Initial Capacity & 85,000 & 65,000 & 27,000 & 425,000 \\
\hline Expanded Capacity $\mathrm{m}^{3} / \mathrm{d}$ & 180,000 & - & - & 600,000 \\
\hline Current inflow $\mathrm{m}^{3} / \mathrm{d}$ & 170,000 & 100,000 & 16,000 & 450,000 \\
\hline $\begin{array}{l}\text { Tertiary treated effluent } \\
\mathrm{m}^{3} / \mathrm{d}\end{array}$ & 166,000 & 98,000 & 15,680 & - \\
\hline RO water treated $\mathrm{m}^{3} / \mathrm{d}$ & - & - & - & 320,000 \\
\hline
\end{tabular}

\subsection{Treatment of Wastewaters that are not connected to the MPW Sewage Network}

As part of the national movement to protect the environment, the local environmental authority had planned to create a sewage pit to replace an existing wastewater dumpsite. This dumpsite was an unlined landfill that accepted wastewater arriving in tank trucks that transport sewage water from remote areas that were not connected to the main MPW network by then (Aleisa and Al-Ahmed 2009). The construction of such pit was of particular importance as it planed pump daily accumulated waste to be treated to tertiary effluent quality at Umm Al Hayman WWTP. Umm AL Hayman was connected to that pit because it was the only plant that is working below the designed capacity and is thus capable of accepting those waters (Aleisa 2008). Over two hundred water tank truck loads that accumulate to over 6000 $\mathrm{m}^{3} /$ day of wastewaters was saved and recycled by accomplishing this project. This pit is temporary until remote areas from which the admitted tank trucks were arriving are connected to the main MPW sewage network.

\section{DESCRIPTION OF THE CURRENT WASTE-WATER NETWORK}

Currently, the country's wastewater network is in a transitional phase. It consists of twelve main pumping stations and four WWTPs. The capacities, current inflows and GPS locations of theses pumping stations are provided in Table 2. The distribution of the pumping stations that are associated with Kuwait City is shown in Figure 1. Main pumping stations are typically denoted by "A", while secondary pumping stations are labeled with "P". Screw lifting stations are denoted with "S". As depicted in Figure 2, stations A3 and A4 are of particular importance as they are located to the largest treatment center in Sulaibiya through A6 and A7. Sulaibiya also receives water from additional two pumping stations A12 and A9. Treated effluent from Sulaibiya is utilized for crops in Al-Abdily, and Wafra farms. On the other hand, Al Jahra WWTP receives water from A18 and A19. Treated effluents from Al Jahra is used for Jahra district Irrigation, and other areas. Riqqa WWTP receives wastewater from A14 through A15. Riqqa treated effluent is used in Ahmadi and Ardiya Data Monitoring Centers (DMC). A20 pumps wastewater to Umm Al Hayman WWTP, which utilizes treated effluents to irrigate golf courses in the country and army bases. Umm Al-Hayman also receives 240 tanks per day from different areas not connected to the wastewater infrastructure.

\section{DATA COLLECTION AND ANALYSIS:}

A daily record for the flow rate in cubic meters for all the WWTPs and main pumping station was collected for the years 2009 and 2010. These records were plotted in time series to monitor seasonality and trends. A sample times-series plot for Umm Al Hayman plant is depicted in Figure 3. An obvious surge appears in rainy seasons. The inflows for all WWTPs and pumping stations were fit into theoretical distributions to be later fed to the simulation model. The distributions are given in Table 3 . 
Table 2: Wastewater Main Pumping Stations in Kuwait

\begin{tabular}{|c|c|c|c|c|c|}
\hline \multicolumn{2}{|c|}{ Pumping station } & \multirow{3}{*}{$\begin{array}{c}\text { Capacity }\left(\mathrm{m}^{3} / \text { day }\right) \\
172,800\end{array}$} & \multirow{3}{*}{$\begin{array}{l}\text { Average Flow ( } \mathrm{m}^{3} / \text { day) } \\
58319\end{array}$} & \multicolumn{2}{|c|}{ Location } \\
\hline & & & & North & East \\
\hline \multirow{7}{*}{$\begin{array}{c}\text { ZONE } \\
\text { (1) }\end{array}$} & A3 & & & $29^{\circ} 22^{\prime} 0.06^{\prime \prime} \mathrm{N}$ & $48^{\circ} 00^{\prime} 38.87^{\prime \prime} \mathrm{E}$ \\
\hline & A4 & 69,120 & 19171 & $29^{\circ} 23^{\prime} 0.95^{\prime \prime} \mathrm{N}$ & $47^{\circ} 59^{\prime} 40.65^{\prime \prime} \mathrm{E}$ \\
\hline & A6 & 172,800 & 123988 & $29^{\circ} 21^{\prime} 37.20^{\prime \prime} \mathrm{N}$ & $47^{\circ} 57^{\prime} 37.59 " \mathrm{E}$ \\
\hline & A7 & 288,000 & 148067 & $29^{\circ} 20^{\prime} 52.43^{\prime \prime N}$ & $47^{\circ} 56^{\prime} 31.82^{\prime \prime E}$ \\
\hline & A8 & 17,420 & 3550 & $29^{\circ} 19^{\prime} 59.01^{\prime \prime N}$ & $47^{\circ} 54^{\prime 25.19 " \mathrm{E}}$ \\
\hline & A9 & 211,200 & 72764 & $29^{\circ} 17^{\prime} 55.39^{\prime \prime} \mathrm{N}$ & $47^{\circ} 55^{\prime} 34.81^{\prime \prime E}$ \\
\hline & A12 & 126,000 & 90483 & $29^{\circ} 17^{\prime} 10.76^{\prime \prime N}$ & $47^{\circ} 55^{\prime} 38.11 " \mathrm{E}$ \\
\hline \multirow{5}{*}{$\begin{array}{c}\text { ZONE } \\
\text { (2) }\end{array}$} & A14 & 176,400 & 138187 & $29^{\circ} 7{ }^{\prime} 37.37 " \mathrm{~N}$ & $48^{\circ} 8^{\prime} 2.23^{\prime \prime} \mathrm{E}$ \\
\hline & A15 & 328,320 & 211887 & $29^{\circ} 7{ }^{\prime} 56.39^{\prime \prime} \mathrm{N}$ & $48^{\circ} 7{ }^{\prime} 34.41^{\prime \prime E}$ \\
\hline & A18 & 100,800 & 55615 & $29^{\circ} 21^{\prime} 4.95^{\prime \prime} \mathrm{N}$ & $47^{\circ} 41^{\prime} 27.82^{\prime \prime} \mathrm{E}$ \\
\hline & A19 & 208,000 & 35375 & $29^{\circ} 18^{\prime} 36.34^{\prime \prime} \mathrm{N}$ & $47^{\circ} 50^{\prime} 2.19^{\prime \prime} \mathrm{E}$ \\
\hline & A20 & 48,080 & 12984 & $28^{\circ} 54^{\prime} 36.23^{\prime \prime} \mathrm{N}$ & $48^{\circ} 13^{\prime} 4.14^{\prime \prime E}$ \\
\hline
\end{tabular}

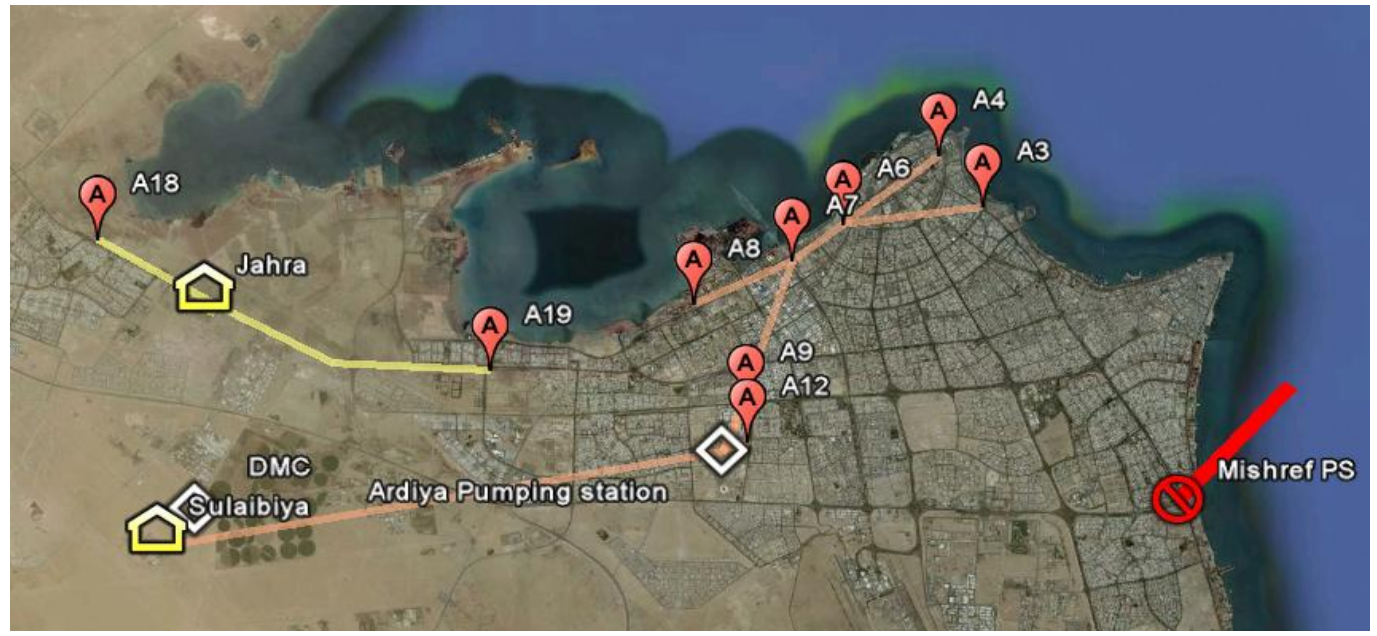

Figure 1: The location of main wastewater pumping stations around Kuwait City

\section{THE SIMULATION MODEL FOR THE WASTEWATER NETWORKS}

A simulation model was constructed using Arena software. Each replication consisted of 365 days to cover the seasonality effect. A flowchart of the model is provided in Figure 4.

\subsection{Validation of the simulation model}

Statistical model validation provides evidence whether or not the model is a legitimate representation of reality (Law and Kelton 2000). A 95\% confidence levels was assumed satisfactory as in any typical validation practice. The equality of the real and simulated population variances were tested first. According to result of the equality of variances test, the proper formula for testing the equality of the real and simulated population is selected and applied. Four replications were conducted for an entire year. 


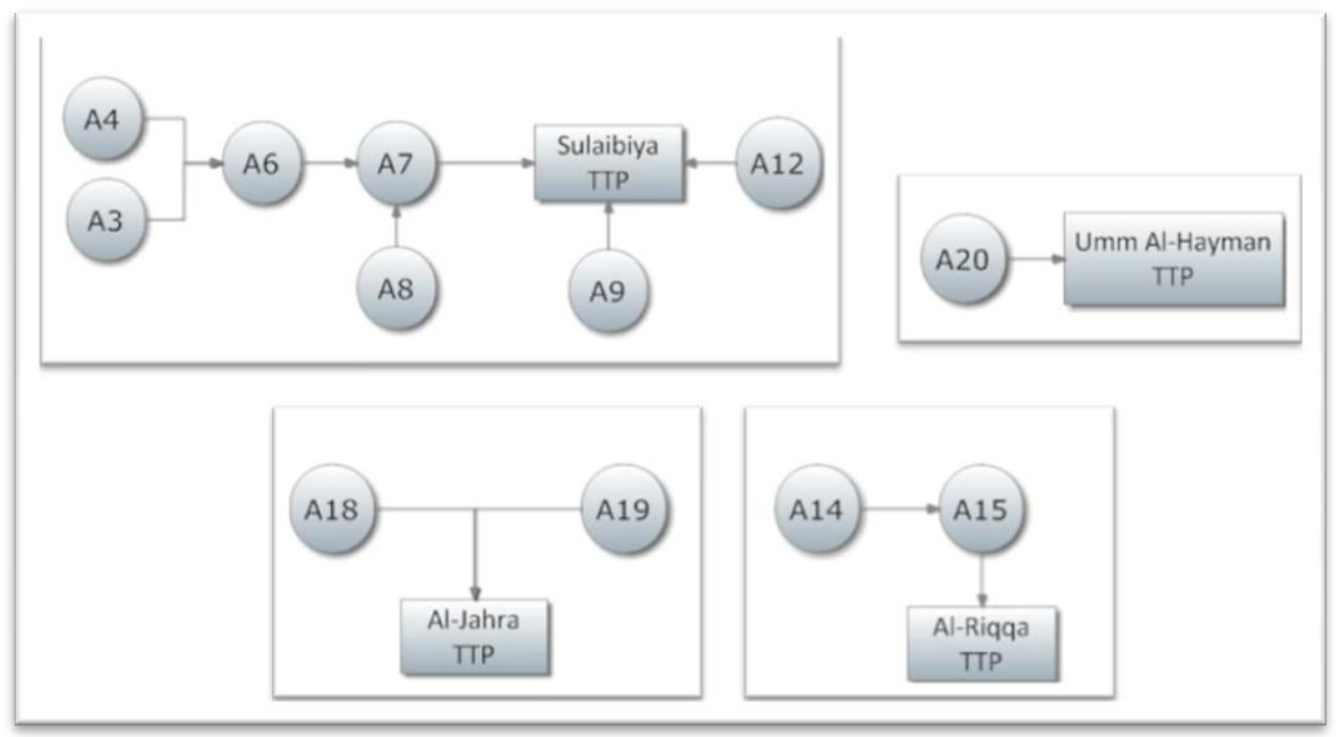

Figure 2: Pictorial flow chart of current connections of Wastewater main pumping stations

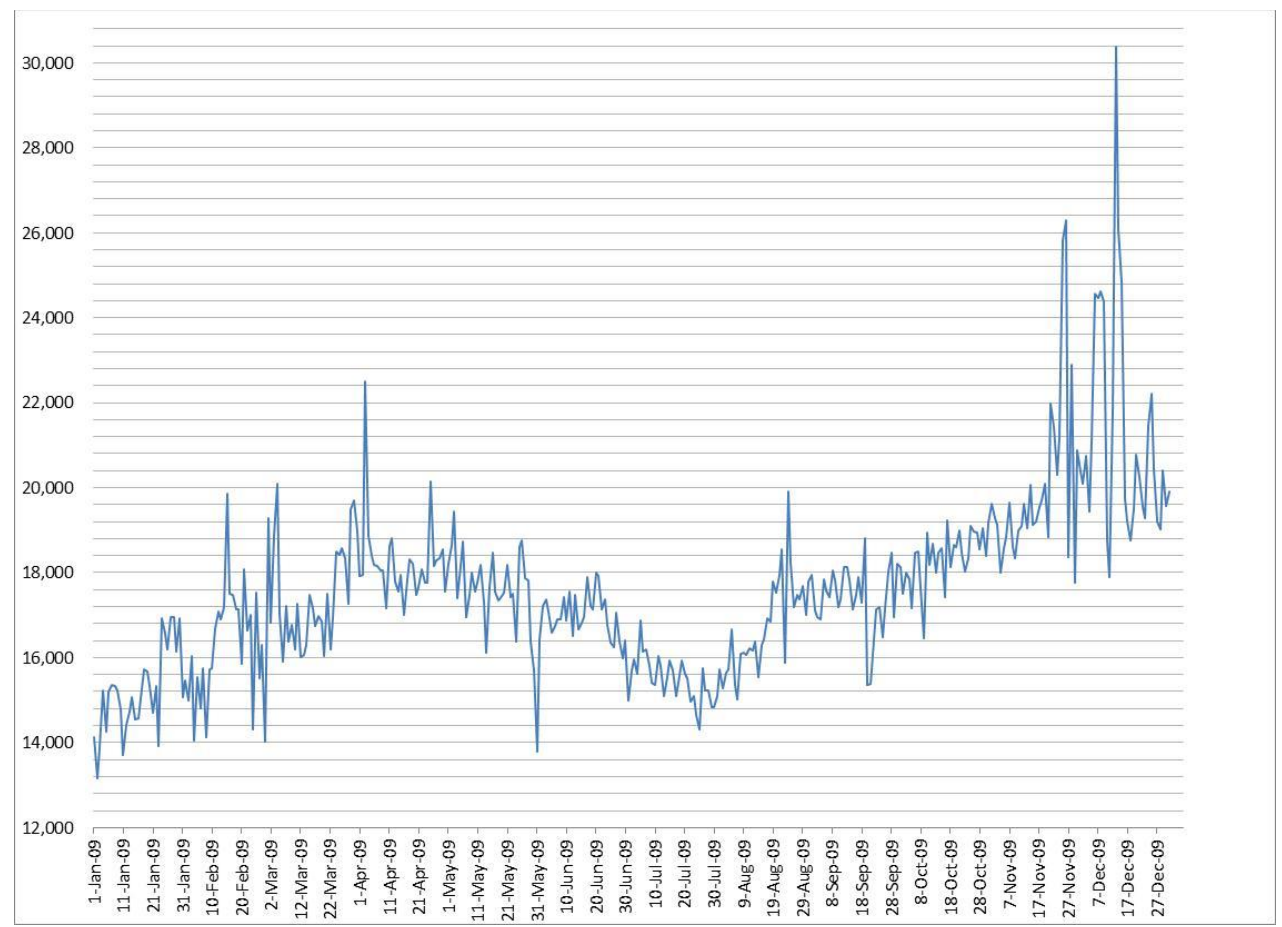

Figure 3: A time series plot for inflows of Umm Al Hayman WWTP for year 2009 
Table 3: Fittings for inflows of wastewaters into main pumping stations

\begin{tabular}{|c|c|}
\hline $\begin{array}{l}\text { A3 } \\
\text { Distribution: Normal } \\
\text { Expression: } \operatorname{NORM}(5.83 \mathrm{e}+004,3.59 \mathrm{e}+003) \\
\text { Square Error: } \quad 0.030145\end{array}$ & $\begin{array}{l}\text { A12 } \\
\text { Distribution: Normal } \\
\text { Expression: } \operatorname{NORM}(9.05 \mathrm{e}+004,1.24 \mathrm{e}+004) \\
\text { Square Error: } \quad 0.148262\end{array}$ \\
\hline $\begin{array}{l}\text { A4 } \\
\text { Distribution: Normal } \\
\text { Expression: NORM }(1.92 \mathrm{e}+004,1.89 \mathrm{e}+003) \\
\text { Square Error: } \quad 0.016721\end{array}$ & $\begin{array}{l}\text { A14 } \\
\text { Distribution: Normal } \\
\text { Expression: NORM }(1.38 \mathrm{e}+005,3.77 \mathrm{e}+003) \\
\text { Square Error: } \quad 0.007789\end{array}$ \\
\hline $\begin{array}{l}\text { A6 } \\
\text { Distribution: Weibull } \\
\text { Expression: } 9.45 \mathrm{e}+004+\operatorname{WEIB}(3.18 \mathrm{e}+004,4.14) \\
\text { Square Error: } \quad 0.008776\end{array}$ & $\begin{array}{l}\text { A15 } \\
\text { Distribution: Normal } \\
\text { Expression: NORM }(2.12 \mathrm{e}+005,8.6 \mathrm{e}+003) \\
\text { Square Error: } \quad 0.005994\end{array}$ \\
\hline $\begin{array}{l}\text { Extra A6 } \\
\text { Distribution: Beta } \\
\text { Expression: } 3.38 \mathrm{e}+004+2.51 \mathrm{e}+004 * \operatorname{BETA}(2.17 \text {, } \\
\text { 2.12) } \\
\text { Square Error: } \quad 0.006839\end{array}$ & $\begin{array}{l}\text { Extra A15 } \\
\text { Distribution: Beta } \\
\text { Expression: } 4.74 \mathrm{e}+004+8.58 \mathrm{e}+004 * \operatorname{BETA}(9.88 \text {, } \\
22.4) \\
\text { Square Error: } \quad 0.007194\end{array}$ \\
\hline $\begin{array}{l}\text { A7 } \\
\text { Distribution: Beta } \\
\text { Expression: } 1.2 \mathrm{e}+005+5.38 \mathrm{e}+004 * \operatorname{BETA}(6.79,6.44) \\
\text { Square Error: } \quad 0.006670\end{array}$ & $\begin{array}{l}\text { A18 } \\
\text { Distribution: Erlang } \\
\text { Expression: } 5.44 \mathrm{e}+004+\operatorname{ERLA}(314,4) \\
\text { Square Error: } \quad 0.003704\end{array}$ \\
\hline $\begin{array}{l}\text { Extra A7 } \\
\text { Distribution: } \\
\text { Expression: } \operatorname{NORM}(2.05 \mathrm{e}+004,4.55 \mathrm{e}+003) \\
\text { Square Error: } \quad 0.003297\end{array}$ & $\begin{array}{l}\text { A19 } \\
\text { Distribution: Beta } \\
\text { Expression: } 3.31 \mathrm{e}+004+3.78 \mathrm{e}+003 * \operatorname{BETA}(15.6,10) \\
\text { Square Error: } \quad 0.011357\end{array}$ \\
\hline $\begin{array}{l}\text { A8 } \\
\text { Distribution: Normal } \\
\text { Expression: } \operatorname{NORM~}(3.55 \mathrm{e}+003,440) \\
\text { Square Error: } \quad 0.009516\end{array}$ & $\begin{array}{l}\text { Extra of Jahra } \\
\text { Distribution: Normal } \\
\text { Expression: } \operatorname{NORM}(2.54 \mathrm{e}+004,2.91 \mathrm{e}+003) \\
\text { Square Error: } \quad 0.065338\end{array}$ \\
\hline $\begin{array}{l}\text { A9 } \\
\text { Distribution: Beta } \\
\text { Expression: } 3.58 \mathrm{e}+004+6.03 \mathrm{e}+004 * \operatorname{BETA}(17.3 \text {, } \\
\text { 10.9) } \\
\text { Square Error: } \quad 0.041131\end{array}$ & $\begin{array}{l}\text { A20 } \\
\text { Distribution: Weibull } \\
\text { Expression: } 1.08 \mathrm{e}+004+\operatorname{WEIB}(2.41 \mathrm{e}+003,1.91) \\
\text { Square Error: } \quad 0.003456\end{array}$ \\
\hline
\end{tabular}

Let $\bar{X}_{i}, s_{i}$ and $n_{i}$ indicate mean, standard deviation and sample size of sample $i$ respectively. Similarly, let $s_{i}^{2}, s_{i}$ and $m_{i}$ indicate the variance, standard deviation and mean of population $i$ respectively. Here we show the results for the Sulaibiya plant:

$\bar{X}_{1}$, actual Sulaibiya $=300623$

$\bar{X}_{2}$, model sulaibiya $=311219$

$S_{1}$, actual Sulaibiya $=50949$

$s_{2}$, model Sulaibiya $=590$

$n_{1}=n_{2}=4$ replications

$\alpha=0.05$

Comparing the equality of the real and simulated population means using population difference confidence Intervals of Minitab Software (Two sample $t$-test) yields: 


$$
-91320 \leq \mu_{1}-\mu_{2} \leq 70126
$$

The $95 \%$ confidence interval on the difference between the real and simulation population means includes zero. This result indicates that the means of these two populations statistically equal at a $95 \%$ confidence level. In other words, the simulation is a valid representation of the real system. The $t$ distribution critical value is -0.42 while the P-value is 0.704 . Similar analyses were conducted to all WWTPs. All were validated at $\alpha=0.05$.

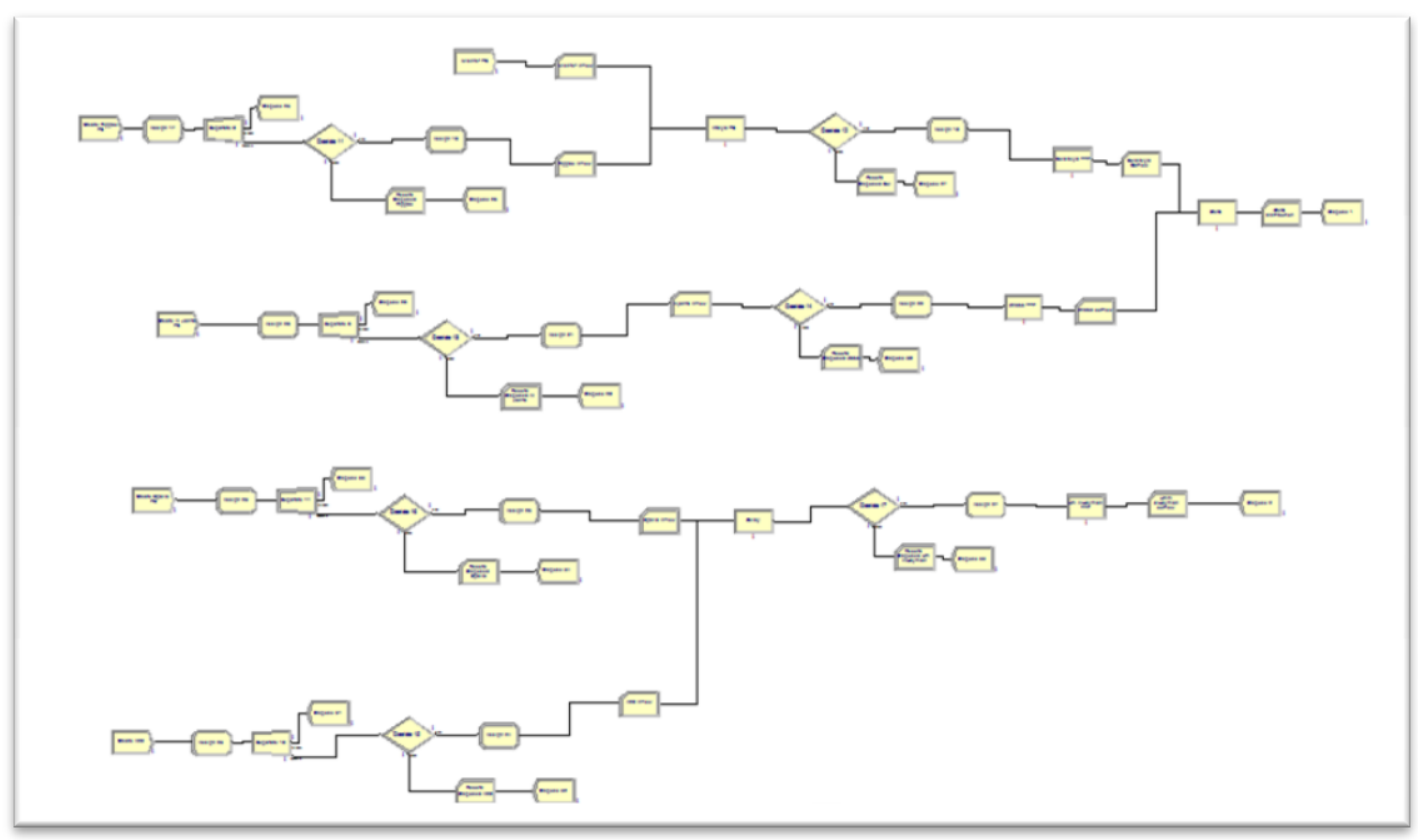

Figure 4: Flowchart of the simulation model of wastewater network in Arena software

\section{FORECASTING FLOW RATES FOR YEAR 2045}

The ministry of planning and public works requested the analyses to be conducted with respect to year 2045. Typical forecasting methodology as moving average, exponential smoothing and regression could not yield realistic results as forecasts were subject to population growth rate. Therefore, inflation formulas for water consumption were used to forecast pumping stations and WWTPs inflows. The formula below shows percent of inflow increase associated with pumping station A18:

\section{DESCRIPTION OF THE FUTURE WASTEWATER NETWORK:}

The wastewater network in Kuwait is undergoing a major transformation (Karam 2010). The changes to the WWTP are provided in Table 4, while changes to main pumping stations are shown in Table 5. A new WWTP, Al-Riqee, is intended to commence in less than a year. Also, new pumping station at the same location is intended to replace 29 older pumping stations. This will indeed reduce operational expenses. This station will have a centralized control system and an advanced odor control. The Al-Riqee pumping station is designed to have a daily pumping capacity of $780,000 \mathrm{~m}^{3}$ (Lidstone 2009). The existing plant capacity Jahra will be replaced by a new WWTP called Kabd. When completed in 2012, the 
Kabd plant will treat about $345,000 \mathrm{~m}^{3} /$ day. The Jahra WWTP will be decommissioned and converted into a pumping station. Um Al Hayman will be expanded to accommodate $500,000 \mathrm{~m}^{3} /$ day. The Riqqa WWTP will be converted into a data monitoring center (DMC). The Sulaibiya WWTP is planned to be expanded to $600,000 \mathrm{~m}^{3} /$ day. Reggae and Mishref pumping stations will pump the wastewater to Ardiya pumping station then to Sulaibiya WWTP. Egaela pumping station will pump the sewage water to A20 (Umm AL Hayman pumping station) then to Umm AL-Hayman WWTP. Khiran treatment center will serves only the coastal area and will receive the sewage water from local pumping and lifting station not a main pumping station.

Table 4: Future WWTPs and expected inflows for year 2045

\begin{tabular}{|c|c|c|c|c|}
\hline \multirow{2}{*}{ WWTPs } & \multirow[t]{2}{*}{ Capacity $\left(\mathrm{m}^{3} /\right.$ day) } & \multirow{2}{*}{$\begin{array}{l}\text { Expected average flow } \\
\left(\mathrm{m}^{3} / \text { day }\right)\end{array}$} & \multicolumn{2}{|c|}{ Location } \\
\hline & & & North & East \\
\hline Sulaibiya & 600,000 & 650,427 & $29^{\circ} 14^{\prime} 48.51^{\prime \prime} \mathrm{N}$ & $47^{\circ} 42^{\prime} 53.39^{\prime \prime} \mathrm{E}$ \\
\hline Kabd & 360,000 & 168,421 & $29^{\circ} 12^{\prime} 24.16^{\prime \prime N}$ & $47^{\circ} 43^{\prime} 7.97^{\prime \prime} \mathrm{E}$ \\
\hline Umm Al-Hayman & 450,000 & 266,309 & $28^{\circ} 52^{\prime} 22.89^{\prime \prime} \mathrm{N}$ & $48^{\circ} 12^{\prime} 36.64^{\prime \prime} \mathrm{E}$ \\
\hline Khiran & 27,000 & - & $28^{\circ} 39^{\prime} 36.15^{\prime \prime} \mathrm{N}$ & $48^{\circ} 22^{\prime} 59.13^{\prime \prime} \mathrm{E}$ \\
\hline
\end{tabular}

Table 5: Main pumping stations of the new wastewater treatment network and expected inflows for year 2045

\begin{tabular}{|l|l|l|l|l|}
\hline \multirow{2}{*}{ Pumping stations } & \multirow{2}{*}{ Capacity $(\mathrm{m} 3 /$ day $)$} & \multirow{2}{*}{$\begin{array}{l}\text { Expected average flow } \\
\left(\mathrm{m}^{3} / \mathrm{day}\right)\end{array}$} & \multicolumn{2}{|c|}{ Location } \\
\cline { 4 - 5 } & & 253,693 & North & East \\
\hline Mishref & 340,000 & 452,015 & $29^{\circ} 16^{\prime} 10.46^{\prime \prime} \mathrm{N}$ & $48^{\circ} 4^{\prime} 56.70^{\prime \prime} \mathrm{E}$ \\
\hline Reggae & 777,600 & 169,056 & $29^{\circ} 18^{\prime} 33.65^{\prime \prime} \mathrm{N}$ & $47^{\circ} 55^{\prime} 11.14^{\prime \prime} \mathrm{E}$ \\
\hline Jahra & 375,000 & $29^{\circ} 19^{\prime} 42.19^{\prime \prime} \mathrm{N}$ & $47^{\circ} 44^{\prime} 8.32^{\prime \prime} \mathrm{E}$ \\
\hline Egaela & 360,000 & 307,391 & $29^{\circ} 9^{\prime} 40.72^{\prime \prime} \mathrm{N}$ & $48^{\circ} 66^{\prime} 30.31^{\prime \prime} \mathrm{E}$ \\
\hline A20 & 48,080 & 18,635 & $28^{\circ} 54^{\prime} 36.09^{\prime \prime} \mathrm{N}$ & $48^{\circ} 13^{\prime} 3.88^{\prime \prime} \mathrm{E}$ \\
\hline
\end{tabular}

\section{ANALYSES OF FUTURE WASTEWATER TREATMENT PLAN SIMUALTION:}

A massive transformation will take place and simulation is used to predict performance of the network. The reduction of pumping stations from twelve to five decreases the complexity of the network. The inflows value at Sulaibiya WWTP will exceed its capacity by an average value of 50,000 m3/day. All other WWTP capacities are sufficient. In 2045 , Sulaibiya will be able to treat up to $42 \%$ of the country's wastewater. In case of any emergency shutdown Sulaibiya, the simulation shows that the newly constructed WWTP at Kabd and Umm Al Hayman can accommodate Sulaibiya but not to RO quality. Regarding main pumping station, A14 will be accepting sewage levels beyond its capacity, while A6, A12, A15, and A18 will be receiving amounts barely reaching their capacities.

\section{CONCLUSION}

This paper describes a large-scale simulation study for modeling a wastewater infrastructure of the country of Kuwait. It also tested the current wastewater infrastructure using forecasted water consumption and showed the urgency for the need of future expansion. The study also simulated the future plan for the wastewater network that is intended to be complete within the next thirty five years. The use of simulation for wastewater network was essential to predict the performance, capacities and emergency precautions for such a huge investment. The simulation revealed which stations will need further expansion by the end of year 2045 and indicated to which stations wastewaters need to be transferred in the case of any 
breakdowns. This effort will assist the country in achieving its strategic goal of zero wastewater dumping and full utilization of treated effluent.

\section{ACKNOWLEDGMENTS}

The authors of this project appreciate the help and support of the following professional for their genuine help and support: Dr. Masud Parkar at Atkins Global Consultants in Kuwait, Eng. Khalid Al Khizzy, Assistant Undersecretary, Sanitary Engineering Division, Ministry of public works, Kuwait. Eng. Mahmoud Khaled Karam, Chief of Engineers of Sanitary Engineering Sector, Ministry of public works, Kuwait and Eng. Samir Lutfi, Operations Manager, Utilities Development Co. (UDC). The authors thank the students Saja Aldhubaibi, Mariam Al Aoun and Salama al Wasmi for the data collection efforts.

\section{REFERENCES}

Al Khizzy, Khalid A. 2009. "Wastewater treatment in the state of Kuwait (in Arabic)," edited by Ministry of public works Sanitary Engineering Division. Kuwait City.

Aleisa, E. 2008. "Developing efficient testing and unloading procedures for a local sewage holding pit." International Journal of Computer, Information, and Systems Science, and Engineering, 2 (3):138145.

Aleisa, Esra, and Mohammad D. Al-Ahmed. 2009. "Application of discrete event simulation to design and management of waste water pit-a case study." Paper read at Proceeding of The 5th IEEE GCC Conference \& Exhibitions (IEEEGCC 2009), March 17-19, at Kuwait City, Kuwait.

Andreottola, G., G. Bortone, and A. Tilche. 1997. "Experimental validation of a simulation and design model for nitrogen removal in sequencing batch reactors." Water Science and Technology no. 35 (1):113-120.

Anonymous. 2010. Sulaibiya Wastewater Treatment and Reclamation Plant, Kuwait. Net Resources International 2009 [cited April, 5 2010]. Available from http://www.watertechnology.net/projects/sulaibiya/.

Batstone, D., J. Keller, B. Newell, and M. Newland. 1997. "Model development and full scale validation for anaerobic treatment of protein and fat based wastewater." Water Science and Technology no. 36 (67):423-431.

Ceric, Vlatko, and V Hlupic. 1993. "Modeling a solid waste-processing system by discrete event simulation." Journal of the Operational Research Society no. 44 (2):107-114.

Enezi, G., M. F. Hamoda, and N. Fawzi. 2004. "Heavy metals content of municipal wastewater and sludges in Kuwait." Journal of Environmental Science and Health Part a-Environmental Science and Engineering \& Toxic and Hazardous Substance Control no. A39 (2):397-407.

Ferrer, J., A. Seco, J. Serralta, J. Ribes, J. Manga, E. Asensi, J. J. Morenilla, and F. Llavador. 2008. "DESASS: A software tool for designing, simulating and optimising WWTPs." Environmental Modelling \& Software no. 23:19-26. doi: 10.1016/j.envsoft.2007.04.005.

Filali-Meknassi, Y., M. Auriol, R. D. Tyagi, Y. Comeau, and R. Y. Surampalli. 2005. "Design strategy for a simultaneous nitrification/denitrification of a slaughterhouse wastewater in a sequencing batch reactor: ASM2d modeling and verification." Environmental Technology no. 26 (10):1081-1100.

Ghobrial, F. H. 1993. "Performance assessment of 3 waste-water WWTPs producing effluents for irrigation." Water Science and Technology no. 27 (9):139-146.

Glenn, S. L., R. T. Norris, and J. T. Sommerfeld. 1990. "Discrete-Event Simulation in Waste-Water Treatment." Journal of Environmental Science and Health Part a-Environmental Science and Engineering \& Toxic and Hazardous Substance Control no. 25 (4):407-423.

Huang, D-B., R. W. Scholz, W. Gujer, D. E. Chitwood, P. Loukopoulos, R. Schertenleib, and Hansruedi Siegrist. 2007. "Discrete event simulation for exploring strategies : An urban water management case " Environmental science \& technology no. 41 (3):915-921. 
Karam, Mahmoud K. 2010. "Utilization of treated effluent in the state of Kuwait," edited by Ministry of public works Sanitary Engineering Division. Kuwait City.

Langergraber, G. 2007. "Simulation of the treatment performance of outdoor subsurface flow constructed wetlands in temperate climates." Science of the Total Environment no. 380 (1-3):210-219. doi: 10.1016/j.scitotenv.2006.10.030.

Law, A. M., and W. D. Kelton. 2000. Simulation Modeling and Analysis 3rd ed: McGraw-Hill Science/Engineering/Math.

Lidstone, Digby 2009. "Kuwait relieving pressure on the wastewater system." Middle East Business Intelligence (MEED), December 1.

Muschalla, D., S. Schneider, V. Gamerith, G. Gruber, and K. Schroter. 2008. "Sewer modelling based on highly distributed calibration data sets and multi-objective auto-calibration schemes." Water Science and Technology no. 57 (10):1547-1554. doi: 10.2166/wst.2008.305.

Printemps, C., A. Baudin, T. Dormoy, M. Zug, and P. A. Vanrolleghem. 2004. "Optimisation of a large WWTP thanks to mathematical modelling." Water Science and Technology no. 50 (7):113-122.

Samuelsson, P., M. Ekman, and B. Carlsson. 2001. "A JAVA based simulator of activated sludge processes." Mathematics and Computers in Simulation no. 56 (4-5):333-346.

\section{AUTHOR BIOGRAPHIES}

ESRA ALEISA is an Assistant Professor in the Industrial and Management Systems Engineering Department, College of Engineering and Petroleum, Kuwait University. She received her B.S. degree in industrial engineering from Kuwait University and her Ph.D. in industrial engineering and production systems from SUNY Buffalo. Her research interests includes, planning and design of large scale facilities, simulation and improvement of manufacturing and service systems, especially of that related to wastewater treatment and reuse. She is a member of Omega Rho, the international operations research honor society, IEEE, INFORMS, IIE, ASEE. Her email address is e.aleisa@ku.edu.kw.

OSAMA AL-KASSAR holds B.S. degree in industrial engineering from Kuwait University. His research interests include simulation and modeling for the wastewater and Geographic Information System (GIS) using ArcGIS Esri Software and. He has been a member and an officer at the IIE student chapter for two years during college. His e-mail is <osama.alkassar@gmail.com>.

ABRAR AL-JADI earned her industrial engineering B.S. degree from Kuwait University. She has done advanced simulation models for wastewater networks. Her senior project included finding optimal locations for future fuel stations in Kuwait using the GIS software. Her e-mail is<eng.a.j@live.com>.

SARAH AL-SABAH earned her industrial engineering B.S. degree from Kuwait University. She has done advanced simulation models for wastewater networks. Her senior project included finding optimal locations for future fuel stations in Kuwait using the GIS software. Her e-mail is

<sarah.alsabah@hotmail.com>.

RANA HISHMI is an Industrial Engineer, received B.S degree in Industrial Engineering from Kuwait University, in 2011. She currently works at the Office of Strategic Planning in the College of Engineering and Petroleum at Kuwait University. Her e-mail is <eng.rana.mahmoud@gmail.com>. 